\title{
Assessment of second-trimester amniocentesis cases: 10-year experience of a tertiary center
}

\author{
Reyhan Gündüz ${ }^{1}$ (D), Senem Yaman Tunç ${ }^{1}$ (D), Rezan Buğday² (D), Diclehan Oral \\ Selahaddin Tekeş ${ }^{3}$ iD , Ahmet Yalınkaya \\ ${ }^{1}$ Department of Gynecology and Obstetrics, Faculty of Medicine, Dicle University, Diyarbakur, Turkey \\ ${ }^{2}$ Clinic of Gynecology and Obstetrics, Cizre Dr. Selahattin Cizrelioğhu State Hospital, Şırnak, Turkey \\ ${ }^{3}$ Department of Medical Biology, Faculty of Medicine, Dicle University, Diyarbakur, Turkey
}

\begin{abstract}
Objective: The aim is to contribute to the literature by carrying out retrospective analysis of the cases who underwent amniocentesis in our clinic and sharing our relevant experience.

Methods: A total of 632 cases who underwent amniocentesis in the second trimester were included in our study. The cases' demographic characteristics, weeks of gestation, amniocentesis indications, procedure-related complications, culture success, cytogenetic results, and the results and indications of the cases found to have chromosomal anomalies were evaluated. Chromosomal anomalies, their complications, culture failure rates and most common amniocentesis indications were reported. The results of the cases with chromosomal anomalies were presented as numerical and structural anomalies.

Results: The mean age of all cases included in our study was $33.7 \pm 6.8$ years, and their mean weeks of gestation were $17.5 \pm 1.0$ weeks. The rate of the cases found to have chromosomal anomaly by amniocentesis was $22.4 \%$, the culture failure rate was $2.1 \%$, and complication rate was $0.5 \%$. The most common amniocentesis indications and the amniocentesis indications in cases found to have chromosomal anomaly were the same, and they were as following respectively: combined test being high risk, triple screening test being high risk and presence of anomaly in the ultrasonography (USG). The rate of detecting chromosomal anomaly was higher in the cases who had multiple indications and underwent amniocentesis.

Conclusion: Although USG and serum screening tests are used commonly for prenatal diagnosis, invasive tests such as amniocentesis are needed for the final diagnosis in patients with high risk. We concluded that amniocentesis is more important for prenatal diagnosis in cases who are under risk of having multiple chromosomal anomalies in the screening tests.
\end{abstract}

Keywords: Amniocentesis, chromosomal anomaly, serum screening tests, ultrasonography.

\section{Özet: İkinci trimester amniyosentez olgularının değerlendirilmesi: Tersiyer bir merkezin 10 yıllık deneyimi}

Amaç: Kliniğimizde amniyosentez uygulanan olguların retrospektif analizini yapmak ve bu konudaki deneyimimizi paylaşarak literatüre katkı sunmaktır.

Yöntem: Calışmamıza ikinci trimesterde amniyosentez uygulanan 632 olgu dahil edildi. Olguların demografik özellikleri, gebelik haftaları, amniyosentez endikasyonları, işleme bağlı komplikasyonları, kültür başarısı, sitogenetik sonuçları, kromozom anomalisi saptanan olguların sonuçları ve endikasyonları değerlendirildi. Kromozom anomalisi, komplikasyonları, kültür başarısızlığı oranları ve en sık amniyosentez endikasyonları belirtildi. Kromozom anomalisi olan olguların sonuçları sayısal ve yapısal anomali olarak belirtildi.

Bulgular: Çalışmamıza dahil edilen tüm olguların yaş ortalamaları $33.7 \pm 6.8$ yl , gebelik haftalar1 $17.5 \pm 1.0$ hafta olarak tespit edildi. Amniyosentez sonucu kromozom anomalisi tespit edilen olgu oran $\% 22.4$, kültür başarısızlığı oranı \%2.1 ve komplikasyon oranı \% 0.5 bulundu. En sik amniyosentez endikasyonları ve kromozom anomalisi tespit edilen olgularda amniyosentez endikasyonları aynı olup bunlar sırasıyla; kombine testin yüksek riskli olması, üçlü tarama testinin yüksek riskli olması ve ultrasonografide (USG) anomali olmasıdır. Kromozom anomalisi tespit etme oranı birden fazla endikasyonun birlikte görülüp amniyosentez uygulanan olgularda daha yüksek bulundu.

Sonuç: Prenatal tanı için USG ve serum tarama testleri yaygın olarak kullanılmakla birlikte yüksek riskli hastalara kesin tanı için amniyosentez gibi invazif testlere ihtiyaç vardır. Tarama testlerinde birden fazla kromozom anomalisi riski taşıyan olgularda, prenatal tanı için amniyosentezin daha önemli olduğu sonucuna varildi.

Anahtar sözcükler: Amniyosentez, kromozom anomalisi, serum tarama testleri, ultrasonografi.

Correspondence: Reyhan Gündüz, MD. Department of Gynecology and Obstetrics, Faculty of Medicine, Dicle University, Diyarbakır, Turkey. e-mail: ryhn.gunduz@gmail.com / Received: December 21, 2020; Accepted: February 3, 2021

How to cite this article: Gündüz R, Yaman Tunç S, Buğday R, Oral D, Tekeş S, Yalınkaya A. Assessment of second-trimester amniocentesis cases: 10-year experience of a tertiary center. Perinatal Journal 2021;29(1):63-70. doi:10.2399/prn.21.0291010

ORCID ID: R. Gündüz 0000-0001-8468-7038; S. Yaman Tunç 0000-0003-2583-2770; R. Buğday 0000-0001-7473-9674;

D. Oral 0000-0002-0074-0602; S. Tekeş 0000-0001-6405-1112; A. Yalınkaya 0000-0002-6644-0186 


\section{Introduction}

About $3 \%$ of live births are affected by a major structural malformation. ${ }^{[1]}$ With the developments in prenatal ultrasonography (USG), most of these anomalies can be detected in the prenatal period today. The etiology is various and includes environmental factors, genetic factors or a combination of both. The presence of a fetal structural anomaly increases the possibility of a chromosomal anomaly or genetic molecular defect, and it should enable to make more assessments for genetic etiologies. The incidence of a chromosomal anomaly depends on the specific anomaly, number of anomalies and the combinations of detected anomalies. ${ }^{[2]}$ The incidence of fetal chromosomal anomalies was reported $2-18 \%$ in isolated fetal anomalies and $13-35 \%$ in multiple fetal anomalies. ${ }^{[2,3]}$

The measurement of increased nuchal thickness in the first trimester, lack of nasal bone or lack of ductus venosus wave form or the presence of reverse flow in USG increases the risk of aneuploidy. In addition to the major structural anomalies related with chromosomal anomalies, the cardiac anomalies, neuroanatomical anomalies and other major structural anomalies which increase the possibility of a genetic condition as well as usually having a functional importance can be detected in USG. ${ }^{[4,5]}$ However, final karyotype analysis diagnosis can only be established through fetal cells. ${ }^{[6]}$

Depending on the week of gestation during diagnosis, chorionic villus sampling (CVS) or amniocentesis may be recommended in order to obtain a fetal sample for genetic test. Amniocentesis is performed optimally after 15 weeks of gestation. When it is carried out in an experienced center, the rate of gestational loss related with the procedure varies between $1 / 300$ and $1 / 1000$ for amniocentesis and CVS. ${ }^{[7]}$

The indications of amniocentesis may change. Amniocentesis may be recommended for those with advanced maternal age ( $>35$ years), family history of genetic disease, women with the history of baby with anomaly, USG results showing fetal abnormalities, positive result in screening test for syndromic babies and positive results in free DNA (cfDNA) test, which is non-invasive prenatal test (NIPT) as the risk of fetal aneuploidy is increased. ${ }^{[8]}$

Preimplantation genetic test (PGT) may allow earlier detection of chromosomal anomalies. This procedure enables to identify anomaly before embryonic transfer, therefore only the unaffected embryos are transferred. In pregnancies conceived by in vitro fertilization (IVF) / PGT, confirmation test by CVS or amniocentesis may be recommended considering the false negativity of fluorescent in situ hybridization (FISH) ${ }^{[9,10]}$

Amniocentesis-related complications are more common in the early weeks of gestation, and the loss of pregnancy associated with this procedure is about $1 / 900 .^{[7]}$

The aim of our study is to assess the indications and results of the cases who underwent amniocentesis in our clinic and to determine the indications to apply amniocentesis in cases found to have chromosomal anomaly.

\section{Methods}

A total of 632 cases who underwent amniocentesis between 2010 and 2020 in the Gynecology and Obstetrics Clinic of the Faculty of Medicine at Dicle University were included in this retrospectively designed study. The approval of the local ethics committee of our university hospital was obtained for our study (Date/number of Ethics Committee Approval: 03.09.2020/no:292).

The cases who underwent amniocentesis in the second trimester for prenatal genetic diagnosis in or clinic were included in the study. The cases who underwent amniocentesis in the third trimester and for the purposes other than prenatal diagnosis as well as the cases who underwent CVS and cordocentesis were excluded from the study. Cases' demographic characteristics, weeks of gestation that the procedure was performed, amniocentesis indications, cytogenetic results, procedure-related complications, culture success of amniocentesis material, and results and indications of the cases found to have chromosomal anomaly were noted. The data were obtained by reviewing hospital database system archive and patient files.

Combined test, triple and quadruplet screening test being high risky, advanced maternal age (35 years and above), anomaly in USG, history of labor with anomaly, maternal anxiety and the indications where a combination of them are seen were considered amniocentesis indications. Estimation values were determined $1 / 250$ for combined test, and $1 / 270$ for triple and quadruplet tests. ${ }^{[1]]}$ 
The expression "anomaly in USG" was used for the patients who were found to have minor sonographic marker (soft marker) or major structural anomaly in USG.

The cases who were diagnosed with the indication routinely in our clinic and recommended to undergo amniocentesis were informed about the procedure in detail and their informed consents were obtained. USG was performed for detailed anatomic examination before the procedure, and abnormal USG results were recorded. The amniocentesis procedure was performed by the specialists with sufficient experience in the field in our clinic in company with USG between 16 and 22 weeks of gestation. Fetal heart rate, fetus position, fetal biometry and placenta location were checked and noted before the procedure. The abdomen was cleaned with antiseptic povidone-iodine, the USG probe was covered with a sterile wrap and it was performed by keeping non-sterile gel within the wrap. In all procedures, 9-15-20 cm 20-22 gauge spinal needles were used. The needle was moved transabdominally in company with USG. When the region, where amniotic fluid sac was located, was entered, about $2 \mathrm{ml}$ was disposed as it might include maternal cells during the passage through maternal abdominal and uterine walls. Afterwards, amniotic fluid was collected by sterile injector without piston as including $1 \mathrm{ml}$ for each week of gestation. $20 \mathrm{ml}$ fluid was collected for pregnancies over 200 weeks of gestation. Fetal heart rate was assessed and noted by USG after the procedure. The procedures followed after amniocentesis in our clinic are as follow: pregnant woman was informed about continuous fluid discharge, vaginal bleeding and uterine contraction, and recommended to apply a health center immediately in case that these conditions develop. Physical and sexual activity restriction was not recommended after the procedure. The blood types of the pregnant women were checked. The pregnant women with Rh incompatibility and whose indirect Coombs test results were negative were applied 300 microgram anti-Rh IgG. Local anesthetic agent was not used during the procedure. Prophylactic antibiotics were not administered to the pregnant women after the procedure, and each pregnant woman was rested after the procedure. All pregnant women were asked to come for control one week after the procedure. Genetic consultancy was provided for each case who was found to have chromosomal anomaly as a result of the amniocentesis, and gestational follow-up and gestational termination options were explained. The complications which developed within a month after the procedure were noted.

The collected amniotic fluids were sent to the Department of Medical Biology and Genetics for chromosome analysis. Chromosomal anomalies (numerical or structural) in all cases were analyzed by using image analysis system in terms of aneuploidy, polyploidy, mosaicism, deletion, duplication, inversion, balanced translocation, unbalanced translocation, ring chromosomes and marker chromosomes. ${ }^{[12]}$

In our study, the amniocentesis results were reported as normal, chromosomal anomaly or failed culture. The cases with chromosomal anomaly were reported as numerical and structural anomalies. SPSS 21 statistics software (IBM Inc., Armonk, NY, USA) was used for statistical analysis. The data were presented as mean, standard deviation, number and percentage.

\section{Results}

A total of 632 cases, who underwent amniocentesis in our clinic during the study period, were found. The mean age of all cases who underwent amniocentesis was $33.7 \pm 6.8$ years, and it was $34.2 \pm 6.9$ for the cases who were found to have chromosomal anomaly as a result of the amniocentesis procedure. Demographic and clinical data are presented in Table $\mathbf{1}$.

Table 1. Assessment of demographic and clinical data.

\begin{tabular}{|c|c|c|c|c|}
\hline & \multicolumn{2}{|c|}{$\begin{array}{l}\text { The data of patients who } \\
\text { underwent amniocentesis }(n=632)\end{array}$} & \multicolumn{2}{|c|}{$\begin{array}{l}\text { The data of patients who were found } \\
\text { to have chromosomal anomaly ( } n=142)\end{array}$} \\
\hline & Mean \pm SD & $($ Min-max) & Mean \pm SD & (Min-max) \\
\hline Age (year) & $33.7 \pm 6.8$ & $(16-52)$ & $34.2 \pm 6.9$ & $(17-49)$ \\
\hline Gravida & $4.5 \pm 2.6$ & $(1-15)$ & $4.8 \pm 2.7$ & $(1-12)$ \\
\hline Parity & $2.9 \pm 2.3$ & $(0-11)$ & $3.2 \pm 2.5$ & $(0-10)$ \\
\hline Week of gestation & $17.5 \pm 1.0$ & $(16-22)$ & $17.5 \pm 1.0$ & $(16-22)$ \\
\hline
\end{tabular}


Table 2. Assessment of amniocentesis indications

\begin{tabular}{|c|c|c|c|c|c|}
\hline & \multicolumn{2}{|c|}{$\begin{array}{l}\text { Amniocentesis } \\
\quad(n=632)\end{array}$} & \multicolumn{2}{|c|}{$\begin{array}{c}\text { The patients who were } \\
\text { found to have chromosomal } \\
\text { anomaly ( } n=142)\end{array}$} & \multirow{2}{*}{ 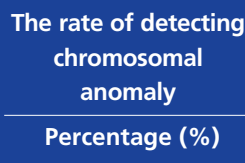 } \\
\hline & n & Percentage (\%) & $\mathbf{n}$ & Percentage (\%) & \\
\hline Combined test being high risk & 240 & 38 & 49 & 34.5 & 20.4 \\
\hline Triple screening test being high risk & 215 & 34 & 43 & 30.3 & 20 \\
\hline Anomaly in USG & 81 & 12.8 & 23 & 16.2 & 28.3 \\
\hline Advanced maternal age & 57 & 9 & 15 & 10.6 & 26.3 \\
\hline History of labor with anomaly & 15 & 2.4 & 6 & 4.2 & 40 \\
\hline Quadruplet screening test being high risk & 4 & 0.6 & 1 & 0.7 & 25 \\
\hline Maternal anxiety & 10 & 1.6 & 0 & 0 & 0 \\
\hline Advanced maternal age + anomaly in USG & 2 & 0.3 & 1 & 0.7 & 50 \\
\hline $\begin{array}{l}\text { Advanced maternal age }+ \text { triple screening } \\
\text { test being high risk }\end{array}$ & 5 & 0.8 & 2 & 1.4 & 40 \\
\hline $\begin{array}{l}\text { Anomaly in USG + triple screening test } \\
\text { being high risk }\end{array}$ & 3 & 0.5 & 2 & 1.4 & 67 \\
\hline
\end{tabular}

It was found that amniocentesis indications in all cases were high risk combined test $(n=240,38 \%)$, high risk triple screening test $(\mathrm{n}=215,34 \%)$ and anomaly in USG ( $n=81,12.8 \%)$. The numbers of cases found to have chromosomal anomaly were $n=49(34.5 \%), n=43$ $(30.3 \%)$ and $n=23(16.2 \%)$, respectively by the same indications. The rate of detecting chromosomal anomaly in cases who underwent amniocentesis due to high risk of anomaly in USG and triple screening test was $67 \%$ while it was $40 \%$ in cases with the history of labor with anomaly. Chromosomal anomaly was not found in the results of $10(1.6 \%)$ cases who underwent amniocentesis due to maternal anxiety (Table 2).

When we reviewed the genetic results of the cases who underwent amniocentesis, we found that chromo-

Table 3. Assessment of clinical data.

\begin{tabular}{llcc} 
& & n & Percentage (\%) \\
\hline \multirow{2}{*}{ Chromosomal result } & Normal & 477 & 75.5 \\
& Abnormal & 142 & 22.4 \\
& Failed culture result & 13 & 2.1 \\
\hline \multirow{2}{*}{ Culture result } & Successful & 619 & 97.9 \\
& Failed & 13 & 2.1 \\
\hline Singleton / & Singleton & 628 & 99.4 \\
multiple pregnancy & Multiple & 4 & 0.6 \\
\hline Complication & Available & 3 & 0.5 \\
& Not available & 629 & 99.5 \\
\hline
\end{tabular}

somal anomaly rate was $22.4 \%(n=142)$, complication rate was $0.5 \%(n=3)$, and the rate of culture failure was $2.1 \%(n=13)$ (Table 3). In our study, the results of chromosomal anomaly were presented separately as numerical and structural anomalies (Table 4). Of the cases who were found to have chromosomal anomaly, one $(0.7 \%)$ had both structural and numerical anomalies, 43 (30.2\%) had numerical anomaly, and 98 (69\%) had structural anomaly. It was found that $46,==, 9 \mathrm{qh}+$ anomaly $(29.5 \%)$ was the most common anomaly in the structural anomalies, and $47,==,+21$ anomaly (Down syndrome) $(17.6 \%)$ was the most common in the numerical anomalies. $46,==, 9 \mathrm{qh}+$ anomaly represents the increase in the heterochromatin region of $\mathrm{q}$ arm (long arm) of 9th chromosome. Polymorphism does not cause anomaly as phenotype in affected individuals, and it is an anomaly compatible with life.

\section{Discussion}

Amniocentesis is an invasive test used for prenatal genetic diagnosis although it has complication risk. Amniocentesis is important for final diagnosis although USG and serum screening tests are used commonly. However, as we cannot perform amniocentesis which is an invasive procedure in all pregnant women, we need to know which amniocentesis indications we should attach importance more. 
Table 4. Assessment of detected chromosomal anomalies.

\begin{tabular}{|c|c|c|}
\hline Structural anomalies & Numerical anomalies & Structural and numerical anomalies \\
\hline $46,==, 21 \mathrm{ps}+$ & $47,==,+18 \quad($ Edward's syndrome $)$ & $47,==, 22 p s+,+18$ \\
\hline $46,==, 9 q h+$ & Complex aneuploidy & \\
\hline $46,==, 9 q h+, 15 p s+$ & $47 X Y Y$ & \\
\hline $46,==, 1 \mathrm{qh}+$ & $47,==,+13$ (Patau's syndrome) & \\
\hline $46,==, 13 p s+, 15 p s+$ & 47,XXY (Klinefelter syndrome) & \\
\hline $\operatorname{mos} 46,==, t(1 ; 3)[4] / 46,==[22]$ & $47,==,+21$ (Down syndrome) & \\
\hline $46,==, \operatorname{inv}(9)(p 13 ; q 13)$ & 47,XXX (Triple X syndrome) & \\
\hline $46,==, 22 p s+$ & $46, X X(2) / 47, X X,+\operatorname{mar}(23)$ & \\
\hline $46,==, \operatorname{inv}(9)(q 11 q 13)$ & $45, X$ (Turner syndrome) & \\
\hline \multicolumn{3}{|l|}{ Fragil-X syndrome } \\
\hline \multicolumn{3}{|l|}{$46==, 1 q h+, 9 q h+$} \\
\hline \multicolumn{3}{|l|}{$46,==, 9 q \mathrm{qh}+, 14 \mathrm{ps}+, 15 \mathrm{ps}+, 22 \mathrm{ps}+$} \\
\hline \multicolumn{3}{|l|}{$46,==, 16 q h+$} \\
\hline \multicolumn{3}{|l|}{$46,==, 13 \mathrm{ps}+, 22 \mathrm{ps}+$} \\
\hline \multicolumn{3}{|l|}{$46,==, 14 \mathrm{ps}+$} \\
\hline \multicolumn{3}{|l|}{$46,==, 14 \mathrm{ps}+, 15 \mathrm{ps}+$} \\
\hline \multicolumn{3}{|l|}{$46, X, \operatorname{inv}(Y)$} \\
\hline \multicolumn{3}{|l|}{$46,==, 13-14$ ps +} \\
\hline \multicolumn{3}{|l|}{$46,==, \operatorname{inv}(9)$} \\
\hline \multicolumn{3}{|l|}{$46,==, 22 p s+$} \\
\hline \multicolumn{3}{|l|}{$46,==, 15 p s+$} \\
\hline \multicolumn{3}{|l|}{$46,==\operatorname{inv}(9)(p 12 ; q 13)$} \\
\hline $46,==, 1 q h+, \operatorname{inv}(9)(p 13 ; q 13)$ & & \\
\hline
\end{tabular}

inv: inversion; mos: mosaic; p: short arm of chromosome; ps+: satellite increase on p arm (short arm) of chromosome; q: long arm of chromosome; qh+: increase in heterochromatin region of $\mathrm{q}$ arm (long arm) of chromosome.

In a study including 12,365 cases who underwent amniocentesis for prenatal diagnosis, the most common indications to apply amniocentesis were reported as maternal serum screening test being abnormal (40.1\%), advanced maternal age (34.5\%), and anomaly in USG $(8.1 \%)$, respectively. The most frequent indication which detected the cases with chromosomal anomaly was the presence of chromosomal anomaly in one of the parents $(57.4 \%)$, which was followed by the detection of anomaly in USG (8.5\%). ${ }^{[13]}$ An et al. performed amniocentesis on 2500 cases in the second trimester, and they reported the most common three indications in these cases as maternal serum screening test being positive $(69.5 \%)$, advanced maternal age (15\%), and the combination of maternal serum screening test positivity and advanced maternal age (8.9\%). When the authors evalu- ated the indications in terms of detecting chromosomal anomaly, they found that they could detect chromosomal anomalies more frequently by the combination of maternal serum screening positivity and advanced maternal age $(14.3 \%)$ as separate and individual indications compared to the cases who underwent amniocentesis. ${ }^{[14]}$ When we evaluated the indications of all cases who underwent amniocentesis in our study, we found that the combined test being high risk, the triple screening test being high risk, and the presence of anomaly in USG were the most common three indications. However, when we assessed the indications to apply amniocentesis in patients who were detected to have chromosomal anomaly, we found that the rate of detecting chromosomal anomaly was most frequent in the cases who underwent amniocentesis due to multiple 
indications. Apart from these, the anomaly was found with a rate of $40 \%$ in cases who underwent amniocentesis due to the indication of history of labor with anomaly as a single indication. These indications are followed by the presence of anomaly in USG (28.3\%), advanced maternal age $(26.3 \%)$, combined test being high risk $(20.4 \%)$ and triple screening test being high risk (20\%). No anomaly was found in any case who underwent the procedure due to maternal anxiety. Similar to the study of An et al., ${ }^{[14]}$ we found the incidence of chromosomal anomaly proportionately higher in the cases who underwent amniocentesis due to the indication where multiple indications were together in our study.

Our most frequent indication to apply amniocentesis was the screening tests being high risk similar to those studies. We associate the reason with the prevalent use of screening tests. Unlike these studies, we found in our study that the rate of amniocentesis performed due to the indication of advanced maternal age was $9 \%$. We believe that the reason is associated with the fact that the pregnant women did not accept amniocentesis procedure, which is an invasive test, just for the indication of advanced age in our study population.

In the study of An et al., the authors reported the rate of chromosomal anomaly $8.4 \%$. Of them, $33 \%$ were numerical anomaly and $19.9 \%$ were structural anomaly. ${ }^{[14]}$ Tao et al. found chromosomal anomaly in $2.88 \%$ of 4761 cases who underwent amniocentesis in the second trimester, where $89.1 \%$ of them were numerical and $10.9 \%$ of them were structural anomalies. Trisomy 21 $(59 \%)$ was the most frequent result among the numerical anomalies. In the same study, the rate of culture failure was reported $1.7 \%{ }^{[15]}$ Balc1 et al. reported the rate of culture failure $2.1 \%$ and chromosomal anomaly $4.6 \%$ in the cases who underwent amniocentesis in the second trimester. The same study reported fetal loss with a rate of $0.48 \%$ as a complication. ${ }^{[16]}$ In our study, we found the rate of chromosomal anomaly $22.4 \%$, complication rate $0.5 \%$, and the rate of culture failure $2.1 \%$. Of the cases with chromosomal anomaly, $30.2 \%$ were numerical anomaly and $69 \%$ were structural anomaly. The most common anomaly among the numerical anomalies was trisomy 21 . We found different rates when we reviewed the studies in the literature carried out led by these studies. We think that the reason varies according to the indication to apply amniocentesis, the technique used for amniocentesis and the laboratory that process the material. In addition, we believe that we obtained high rates of chromosomal anomaly in our study than other studies because our center is a referral university hospital.

Some studies reported fetal loss rate after amniocentesis in multiple pregnancies between $2.7 \%$ and $3.2 \% .^{[17,18]}$ In our study, 4 cases $(0.6 \%)$ who underwent amniocentesis had multiple pregnancy. We did not find chromosomal anomaly in three of them, but found culture failure in one case. We could not detect any complication. All complications with a rate of $0.5 \%$ in our study were in singleton pregnancies.

NIPT or free DNA test is the most sensitive and specific screening test for the most common fetal aneuploidies. Yet, it has the potential to provide false positive or false negative result. Moreover, free DNA test is not equivalent for diagnostic tests. ${ }^{[19]}$ When we reviewed the study which was conducted on 31,515 women with singleton pregnancy who underwent NIPT, we found that the patients with positive results for sex chromosomal aneuploidy or trisomy as a result of NIPT underwent amniocentesis or cordocentesis between 18 and 23 weeks of gestation, and the sensitivity and specificity of NIPT were analyzed. The authors concluded that many unnecessary invasive prenatal diagnosis cases could be avoided upon the integration of NIPT to current clinical practices, intrauterine infection, miscarriage and preterm labor risks could be decreased, but cost-effectiveness of prenatal screening and diagnosis would increase significantly. ${ }^{[20]}$ Another study included 6239 pregnant women who underwent NIPT in the first and second trimesters. Amniocentesis was performed for patients with high risk for fetal chromosomal deletion, duplication and sex chromosomal anomaly as a result of NIPT. In the conclusion part, the authors reported that NIPT has a good application value to predict fetal chromosomal deletion, duplication and sex chromosomal anomalies and it could increase the detection rate of fetal chromosomal anomalies. ${ }^{[2]}$

In our study, we could not find free DNA test, which has the highest rate to detect aneuploidy among the screening tests in recent years, among our amniocentesis indications. We believe that it is because the socio-economic levels of the patients referred to our center are low, NIPT is expensive in Turkey and the payments are not covered by social security system.

Mosaic embryos which are characterized by the presence of a combination of diploid and aneuploid cell lines and locate completely between euploid and abnormal embryos are not used for transfer usually, because they 
are considered abnormal. ${ }^{[22]}$ However, sometimes, normal embryo cannot be found to transfer. Hong et al. retrospectively reviewed the clinical gestational outcomes and amniocentesis results of mosaic embryos transferred during 28 PGT cycles, and they concluded that the underlying risk should be informed exactly if mosaic embryo would be transferred when there is no normal embryo to transfer in PGT cycles. ${ }^{[23]}$ In our study, there is no case who underwent amniocentesis due to this indication depending on the low numbers of cases who conceived pregnancy by IVF/PGT and the requests of gestational termination.

As the limitation of our study, we could not find the cases who underwent transplacental amniocentesis or did not have clear amniotic fluid as we accessed the data through patient files and hospital archive. Therefore, we do not know how this affects the rates of complication and culture failure. As the strength of our study, we believe that including the data of a single hospital and also conducting amniocentesis procedure by an experienced them increase the reliability of the results.

\section{Conclusion}

Amniocentesis is an invasive procedure which should be performed and rarely has complications when it is conducted by experienced specialists. Although USG and serum screening tests are used commonly in prenatal diagnosis, invasive diagnostic tests should not be neglected if there is an indication. The presence of multiple amniocentesis indications increases the risk of chromosomal anomaly, and therefore, we believe that these patients should be recommended undergoing amniocentesis.

Funding: This work did not receive any specific grant from funding agencies in the public, commercial, or not-for-profit sectors.

Compliance with Ethical Standards: The authors stated that the standards regarding research and publication ethics, the Personal Data Protection Law and the copyright regulations applicable to intellectual and artistic works are complied with and there is no conflict of interest.

\section{References}

1. McCormick AC, McIntosh JJ, Gao W, Hibbard JU, Cruz MO. The impact of fetal anomalies on contemporary labor patterns. Am J Perinatol 2019;36:1423-30. [PubMed] [CrossRef]

2. Staebler M, Donner C, Van Regemorter N, Duprez L, De Maertelaer V, Devreker F, et al. Should determination of the karyotype be systematic for all malformations detected by obstetrical ultrasound? Prenat Diagn 2005;25:567-73. [PubMed] [CrossRef]

3. Bijok J, Massalska D, Kucifska-Chahwan A, Posiewka A, Ilnicka A, Jakiel G, et al. Complex malformations involving the fetal body wall - definition and classification issues. Prenat Diagn 2017;37:1033-9. [PubMed] [CrossRef]

4. American College of Obstetricians and Gynecologists' Committee on Practice Bulletins-Obstetrics and the American Institute of Ultrasound in Medicine. Practice Bulletin No. 175: Ultrasound in pregnancy. Obstet Gynecol 2016;128: e241-56. [PubMed] [CrossRef]

5. Alldred SK, Takwoingi Y, Guo B, Pennant M, Deeks JJ, Neilson JP, et al. First trimester ultrasound tests alone or in combination with first trimester serum tests for Down's syndrome screening. Cochrane Database Syst Rev 2017;3(3): CD012600. [PubMed] [CrossRef]

6. Alfirevic Z, Navaratnam K, Mujezinovic F. Amniocentesis and chorionic villus sampling for prenatal diagnosis. Cochrane Database Syst Rev 2017;9(9):CD003252. [PubMed] [CrossRef]

7. American College of Obstetricians and Gynecologists' Committee on Practice Bulletins-Obstetrics, Committee on Genetics, Society for Maternal-Fetal Medicine. Practice Bulletin No. 162: prenatal diagnostic testing for genetic disorders. Obstet Gynecol 2016;127:e108-22. [PubMed] [CrossRef]

8. Ghi T, Sotiriadis A, Calda P, Da Silva Costa F, RaineFenning N, Alfirevic Z, et al.; International Society of Ultrasound in Obstetrics and Gynecology (ISUOG). ISUOG Practice Guidelines: invasive procedures for prenatal diagnosis. Ultrasound Obstet Gynecol 2016;48:256-68. [PubMed] [CrossRef]

9. Audibert F, Wilson RD, Allen V, Blight C, Brock JA, Desilets VA, et al.; Genetics Committee. Preimplantation genetic testing. J Obstet Gynaecol Can 2009; 31:761-75. [PubMed] [CrossRef]

10. DeUgarte CM, Li M, Surrey M, Danzer H, Hill D, DeCherney AH. Accuracy of FISH analysis in predicting chromosomal status in patients undergoing preimplantation genetic diagnosis. Fertil Steril 2008; 90:1049-54. [PubMed] [CrossRef]

11. Timur A, Uyar İ, Gülhan İ, Tan Saz N, İleri A, Özeren M. The analysis of amniocentesis results of pregnants who are at 16-22 weeks of gestation and undergone genetic amniocentesis. Perinatal Journal 2013;21:101-6. [CrossRef]

12. Zhang Y, Wu J, Li X, Lei C, Xu J, Yin M. Karyotype analysis of amniotic fluid cells and comparison of chromosomal abnormality rate during second trimester. [Article in Chinese] Zhonghua Fu Chan Ke Za Zhi 2011;46:644-8. [PubMed]

13. Xiao H, Yang YL, Zhang CY, Liao EJ, Zhao HR, Liao SX. Karyotype analysis with amniotic fluid in 12365 pregnant women with indications for genetic amniocentesis and strategies of prenatal diagnosis. J Obstet Gynaecol 2016;36:293-6. [PubMed] [CrossRef]

14. An N, Li LL, Wang RX, Li LL, Yue JM, Liu RZ. Clinical and cytogenetic results of a series of amniocentesis cases from Northeast China: a report of 2500 cases. Genet Mol Res 2015; 14:15660-7. [PubMed] [CrossRef] 
15. Tao H, Xiao J, Yang C, Wang J, Tang Y, Guo C, et al. Retrospective analysis of 4761 cases who underwent amniocentesis in southeast China. J Obstet Gynaecol 2018;38:38-41. [PubMed] [CrossRef]

16. Balcı O, Büyükdoğan M, Özdemir S, Mahmoud AS, Acar A, Zamani A. The evaluation of amniocentesis cases made for genetic examination in one-year period. Selçuk Üniversitesi Tip Dergisi 2011;27:6-10.

17. Lenis-Cordoba N, Sanchez MA, Bello-Munoz JC, SagalaMartinez J, Campos N, Carreras-Moratonas E, et al. Amniocentesis and the risk of second trimester fetal loss in twin pregnancies: results from a prospective observational study. J Matern Fetal Neonatal Med 2013;26:1537-41. [PubMed] [CrossRef]

18. Cahill AG, Macones GA, Stamilio DM, Dicke JM, Crane JP, Odibo AO. Pregnancy loss rate after mid-trimester amniocentesis in twin pregnancies. Am J Obstet Gynecol 2009;200: 257.e1-6. [PubMed] [CrossRef]

19. American College of Obstetricians and Gynecologists' Committee on Practice Bulletins-Obstetrics; Committee on
Genetics; Society for Maternal-Fetal Medicine. Screening for fetal chromosomal abnormalities: ACOG Practice Bulletin, Number 226. Obstet Gynecol 2020;136:e48-69. [PubMed] [CrossRef]

20. Xu L, Huang H, Lin N, Wang Y, He D, Zhang M, et al. Noninvasive cell-free fetal DNA testing for aneuploidy: multicenter study of 31515 singleton pregnancies in southeastern China. Ultrasound Obstet Gynecol 2020;55:242-7. [PubMed] [CrossRef]

21. Yin L, Tang Y, Lu Q, Pan A, Shi M. Application value of NIPT for uncommon fetal chromosomal abnormalities. Mol Cytogenet 2020;13:39. [PubMed] [CrossRef]

22. Harton GL, Cinnioglu C, Fiorentino F. Current experience concerning mosaic embryos diagnosed during preimplantation genetic screening. Fertil Steril 2017;107:1113-9. [PubMed] [CrossRef]

23. Hong B, Hao Y. The outcome of human mosaic aneuploid blastocysts after intrauterine transfer. Medicine (Baltimore) 2020;99:e18768. [PubMed] [CrossRef]

This work is licensed under the Creative Commons Attribution-NonCommercial-NoDerivs 4.0 Unported (CC BY-NC-ND4.0) License. To view a copy of this license, visit http://creativecommons.org/licenses/by-nc-nd/4.0/ or send a letter to Creative Commons, PO Box 1866, Mountain View, CA 94042, USA.

Publisher's Note: The content of this publication does not necessarily reflect the views or policies of the publisher, nor does any mention of trade names, commercial products, or organizations imply endorsement by the publisher. Scientific and legal responsibilities of published manuscript belong to their author(s). The publisher remains neutral with regard to jurisdictional claims in published maps and institutional affiliations. 